\title{
Personal Attribute
}

National Cancer Institute

\section{Source}

National Cancer Institute. Personal Attribute. NCI Thesaurus. Code C19332.

The distinguishing qualities or prominent aspects of an individual person. 